Int. J. Dev. Biol. 48: 719-729 (2004)

doi: $10.1387 / \mathrm{ijdb} .041851 \mathrm{jp}$

\title{
Cubozoan jellyfish: an Evo/Devo model for eyes and other sensory systems
}

\author{
JORAM PIATIGORSKY*,1 and ZBYNEK KOZMIK ${ }^{2}$ \\ ${ }^{1}$ National Eye Institute, National Institutes of Health, Bethesda, Maryland, USA and ${ }^{2}$ Institute of Molecular Genetics, \\ Prague, Czech Republic
}

\begin{abstract}
Cnidaria are the most basal phylum containing a well-developed visual system located on specialized sensory structures (rhopalia) with eyes and statocyts. We have been exploring the cubozoan jellyfish, Tripedalia cystophora. In addition to containing simple photoreceptive ocelli, each rhopalium in Tridedalia has a large and small complex, camera-type eye with a cellular lens containing three distinct families of crystallins which apparently serve non-lenticular functions. Thus, Tridpedalia recruited crystallins by a gene sharing strategy as have mollusks and vertebrates. Tripedalia has a single $P a x$ gene, $P a x B$, which encodes a structural and functional Pax 2/5/8-like paired domain as well as an octapeptide and Pax6-like homeodomain. PaxB binds to and activates Tripedalia crystallin promoters (especially J3-crystallin) and the Drosophila rhodopsin rh6 gene in transfection tests and induces ectopic eyes in Drosophila. In situ hybridization showed that PaxB and crystallin genes are expressed in the lens, retina and statocysts. We suggest from these results that an ancestral PaxB gene was a primordial gene in eye evolution and that eyes and ears (mechanoreceptors) may have had a common evolutionary origin. Thus, the numerous structural and molecular features of Tridpalia rhopalia indicate that ancient cubozoan jellyfish are fascinating models for evo/devo insights into eyes and other sensory systems.
\end{abstract}

KEY WORDS: Cnidaria, rhopalia, eyes/ocelli, mechanoreceptors/ears, PaxB, evolution

\section{Introduction}

Eyes come in many forms and shapes in the animal kingdom (Land and Nilsson, 2002, Tomarev and Piatigorsky, 1996). These include the organelle eyes of some unicellular organisms, the simple eye spots of flatworms, the pin-hole eyes of some invertebrates, the varied compound eyes of insects, the mirror eyes of scallops and the complex, camera-type (lens-containing) eyes sprinkled throughout the animal kingdom. Even complex eyes can be varied and show anatomical differences. For example, the lenscontaining eyes of vertebrates have inverted retinas in which the ciliated photoreceptors lie behind the ganglion cells with respect to the light path, while those of cephalopods (squids and octopus) have (generally) rhabdomeric (microvillar) photoreceptors that are placed in front of the ganglion cells and are the first retinal cells to receive light (Arendt and Wittbrodt, 2001). The development and morphology of the lens and cornea also show differences between the complex eyes of vertebrates and cephalopods (Packard, 1972, Tomarev et al., 1997, West et al., 1995, West et al., 1994).

Despite these variations, recent studies have indicated that all eyes may share a similar developmental cascade of transcription factors, suggesting that eyes have had a common evolutionary ancestor (Gehring and lkeo, 1999). The initial molecular finding for the hypothesis of monophyletic eye evolution was that the gene for the eyeless (ey) mutation in Drosophila is Pax6 (Quiring et al., 1994), the very gene responsible for the Aniridia mutation in humans (Ton et al., 1991) and the Small eye mutation in mice (Hill et al., 1991). Subsequently, it was shown that misexpression of $e y$ or of mouse PaxG in leg, wing or antennae imaginal discs of Drosophila induces supernumerary ectopic eyes in the corresponding adult structures (Halder et al., 1995). These and other experiments showing that Pax6 from many species [i.e., squid (Tomarev et al., 1997), ascidian (Glardon et al., 1997), cephalochordate (Glardon et al., 1998), planarian (Callaerts et al., 1999) and ribbon worm (Loosli et al., 1996)] induce ectopic eyes in the fly have led to the idea that this transcription factor is encoded by a 'master control' gene for eye development (Gehring, 2002, Gehring and Ikeo, 1999). While the Pax6master control gene for eye development has much to offer and has generated a flurry of

Abbreviations used in this paper: ey, eyeless gene.

\footnotetext{
*Address correspondence to: Dr. Joram Piatigorsky. National Eye Institute, National Institutes of Health, Laboratory of Molecular and Developmental Biology, 7 Memorial Drive/Building 7, Room 100A, Bethesda, MD 20892-0704, USA. Fax: +1-301-402-0781. e-mail: joramp@nei.nih.gov
} 
activity in 'evo-devo' studies of the eye, it is complicated by the fact that genes for a number of other transcription factors ( twin of eyeless, sine oculis, optix, eyes absent, dachshund, eye gone and teashirt) also induce ectopic eyes (Kador et al., 1979, Kumar and Moses, 2001b, Pichaud et al., 2001). In addition, eye specification occurs later than thought previously (Baker, 2001, Kumar and Moses, 2001a). Moreover, many of the members of the eye developmental cascade of transcription factors, including Pax6, are also used for the development of other tissues (Hanson, 2001). An example is the use of daschund, eyes absent, six and Paxfamily members for both eye and skeletal muscle development (Heanue et al., 1999, Relaix and Buckingham, 1999). These issues raise concerns connected with the idea of homology due to common developmental pathways (Conway Morris, 2000, Simpson and Price, 2002, van Heyningen and Williamson, 2002). Indeed, eyes from different species may be partially homologous (Gehring and Ikeo, 1999) or show different levels of homology (Land and Nilsson, 2002). A recent study using a host of eye-field transcription factors suggested progressive tissue specification by a self-regulating feedback network, consistent with a partial evolutionary conservation of eye formation (Zuber et al., 2003). A detailed review of the complexity of convergent versus divergent eye evolution at the anatomical level can be found elsewhere (Arendt and Wittbrodt, 2001).

\section{Cubozoan eyes with special reference to Tripedalia}

Cnidaria are the most basal animal phylum (Fig. 1) containing a well-developed visual system. In general among Cnidarians, it is the Cubozoa (known as 'box jellyfish' due to their square shape) that have lens-containing eyes (Coates, 2003, Piatigorsky, 2003b), although a few Hydozoa do as well (for example, Cladonema radiatum) (Weber, 1981) (Fig. 2). Photoreceptive organs in Cnidaria have diverse structures, not only between species but within the same species. The cubozoan that we have been investigating, Tridpedalia cystophora, has four equally spaced sensory structures (called rhopalia) dangling from a stalk and situated within open cavities surrounding the bell (Conant 1897, Laska and Hundgen, 1982, Pearse and Pearse, 1978, Piatigorsky et al., 1989, Yamasu and Yoshida, 1976) (Fig. 3). Each rhopalium has six separate eyes. There are two complex, lens-containing eyes, one larger than the other, situated at right angles to each other and two pairs (one pitshaped, one slit-shaped) of simple ocelli comprising photoreceptors on either side of the complex eyes (Coates, 2003). This eye diversity within Tripedalia may provide new insights into the mechanisms used in evolution for achieving greater anatomical complexity of eyes. In addition to the eyes, each rhopalium of Tripedalia has a prominent statocyst described below. The function of the diverse eyes of Tripedalia is still elusive. Recent studies indicate that the camera-type eye has the ability to form a low resolution image on the photoreceptors despite the proximity of the lens to the retina (Laska and Hundgen, 1982, Pearse and Pearse, 1978, Piatigorsky et al., 1989). The behavioral role of the jellyfish eyes is under investigation (Coates, 2003). It seems likely that investigations of eye development in Cnidaria are directly relevant to eye development in other animal groups. The complex eyes of jellyfish show striking similarities in overall structure with the camera-type eye of vertebrates even though they differ in numerous anatomical details. In addition to a cellular lens and cornea, adult cubomedusan jellyfish eyes have ciliated photoreceptors, as do vertebrate eyes, rather than the

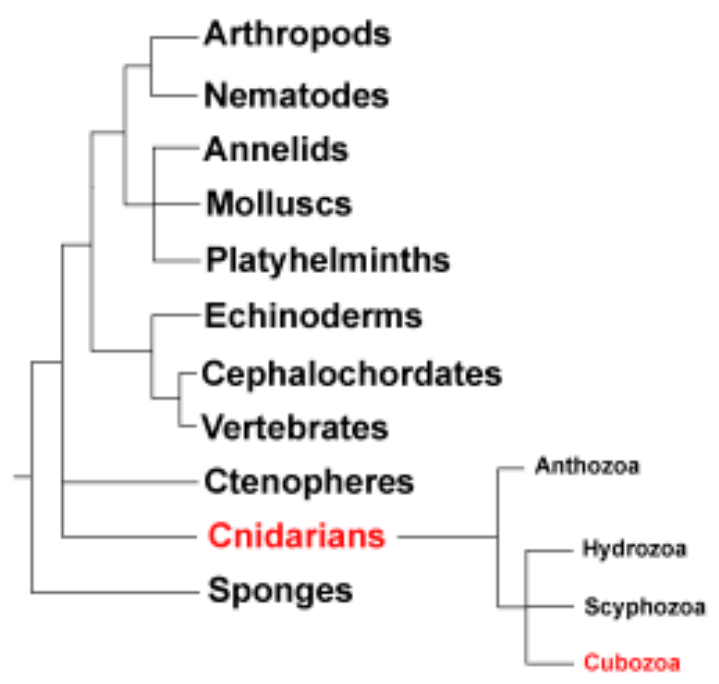

Fig. 1. Phylogenetic relationships among various animal groups. For simplicity, some animal groups have been omitted.

rhabdomeric (microvillar) photoreceptors generally populating invertebrates (Eakin, 1962, Yamasu and Yoshida, 1976). Eakin believed from electron microscopic evidence that there was "a common ancestry of the taxa bearing light-sensitive cilia" (Eakin, 1979); however, close examination of diverse groups shows that the presence of ciliary or rhabdomeric photoreceptors is not neatly divided among species (Arendt and Wittbrodt, 2001). That Cnidarians have many genes believed previously to have arisen with the vertebrates (Ball et al., 2002) provides additional support for the possibility that eye development in jellyfish shares many common features with that of more recently evolved triploblastic metazoans. Indeed, studies have revealed considerable conservation of regulatory genes between the diploblastic cnidarians and chordates (Galliot and Schmid, 2002, Hayward et al., 2002), increasing the likelihood that there is overlap in the mechanisms of eye development between jellyfish and vertebrates. In addition, an investigation of the early embryogenesis of the marine hydrozoan jellyfish, Podocoryne carnea, suggested that the nervous system developed from anterior to posterior in serially repeated patterns, characteristic of bilaterally symmetrical metazoans (Groger and Schmid, 2001). Since jellyfish differ sufficiently from vertebrates, we anticipate that detailed studies of their eye development should provide new insights into whether eyes are monophyletic, convergent, or a combination of both as well as provide new information on eye development in general. There is one caveat concerning the evolutionary aspects of jellyfish eyes that seems appropriate to keep in mind. Although Cnidaria are ancient and predate the Cambrian explosion, the time at which jellyfish evolved eyes is not known. It has been predicted that eyes may develop relatively rapidly during evolution (Nilsson and Pelger, 1994) and it remains possible that jellyfish eyes are relatively recent acquisitions.

\section{Obtaining and culturing Tripedalia for studies on eye development}

One of the difficulties of using Tridpedalia for experiments is obtaining the adult medusae, rearing the embryos through meta- 
Fig. 2. Various types of eyes are found in Cnidaria, ranging from simple eye spots of hydrozoans (A) to complex eyes of cubozoan jellyfish (E). Photoreceptor cells are shown in grey, pigment cells are black. EC, epithelial cells; LB, lens bodies. (A) Primitive eye spot as found in the hydrozoan, Leuckartiara. (B) Everted optic cup closed by a layer of epidermal cells found in hydrozoans Polyorchis and Bougainvillia. (C) Inverted pigment cup of scyphozomedusae, Aurelia. (D) Cladonema ocellus with lens bodies formed as distal cytoplasmatic processes of individual pigment cells. Adjacent epithelial cells extend over the lens bodies to form a primitive "cornea". (E) Complex camera-type eye of the cubomedusan, Tripedalia, containing retina, lens and cornea. (F) Vertebrate eye. (A, B) redrawn after Singla (Singla, 1974); (C) after Hyman (Hyman, 1940); (D) after Weber (Weber, 1981); (E) after Piatigorsky et al., (Piatigorsky et al., 1989).
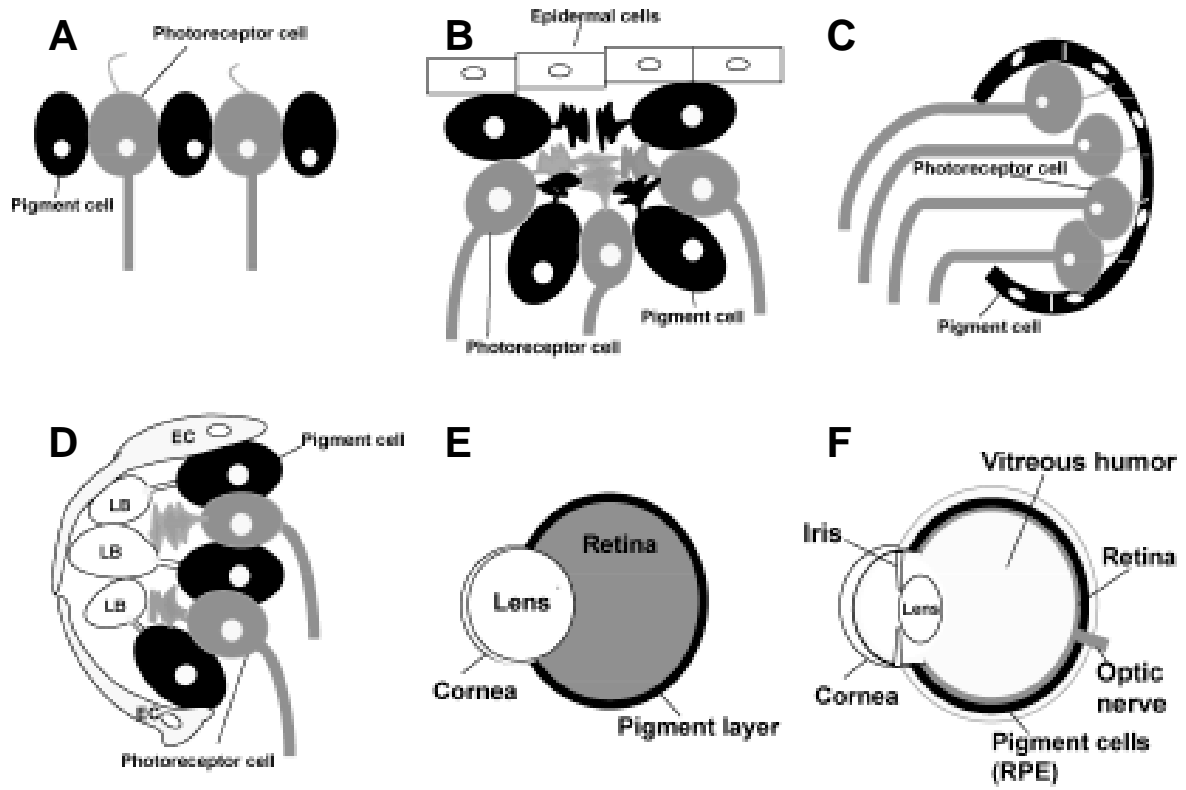

morphosis and culturing the immature medusae to adulthood. We have captured adult Tripedaliamedusae during the summer months swimming along the surface in the mangroves of La Parguera, Puerto Rico, where there is a Marine Station (University of PR). Sunbeams penetrate the foliage and water surface and reflect from the tentacles of the jellyfish. The live animals are caught with a dipnet from a small boat, placed in a bucket containing sea water and taken to the laboratory.

Tripedalia, as other jellyfish, undergo an alternation of generations between sessile, non-sexual polyps and swimming, sexually dimorphic medusae. Their life cycle and successful cultivation have been described (Kostrouch et al., 1998, Werner, 1971). Fertilization is internal and the planulae larvae develop in the gastral pocket of the females; the swimming larvae are released within 2 days into the sea water, settle on the bottom and become pyriform shaped polyps. By the time they form 5 or 6 tentacles near the mouth the primary polyps bud secondary polyps that are eventually released. The primary or secondary polyps grow to approximately $1 \mathrm{~mm}$ in size by $8-10$ weeks and contain a whorl of 7-9 tentacles. Interestingly, the cubozoan polyp of Tridpedalia differs from scypho- and hydrozoan polyps in having a nerve ring before the medusan stage (Werner, 1976). Full-grown polyps metamorphose into swimming ephydrae (immature medusae) within 4 or 5 days. Early studies indicated that the Tridpedalia polyps are fully transformed into the tissues of the medusae (Werner, 1971). This includes the four rhopalia developing at the base of the resorbing polyp tentacles, which group first into a tetraradiate pattern. A new, primary tentacle forms between the rhopalia in the young medusa and within a day two new tentacles form next to each primary tentacle
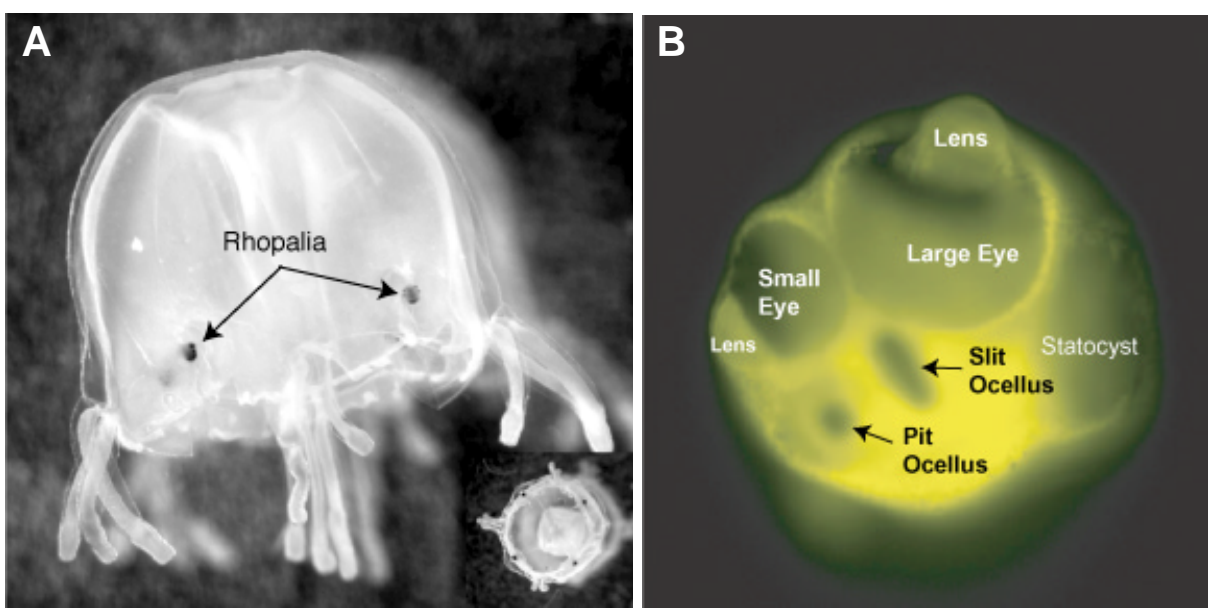

Fig. 3. Tripedalia cystophora medusae (A) and rhopalium (B). Large panel in (A) shows a side view of adult medusae, while the inset represents the bottom view. Rhopalium in (B) has been stained with a fluorescent DNA dye (Hoechst 33342) and pseudocolored in yellow. 


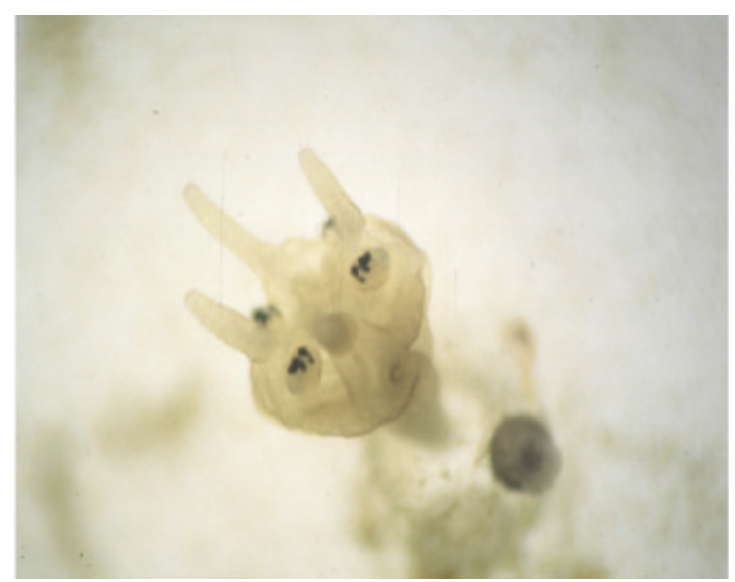

Fig. 4. Newly metamorphosed Tripedalia medusa with the rhopalia situated behind the primary tentacles. See text for further details. Photograph taken by Dr. Zdenek Kostrouch (Institute of Inherited Metabolic Disorders, Charles University, First Faculty of Medicine, Prague, Czech Republic).

netic inheritance of crystallins, such as for example the $\delta$-crystallins in birds and reptiles (Piatigorsky, 1984), the precise crystallin composition within the lens is not diagnostic for evolutionary relationships. Although the protein(s) used as lens crystallins often differ among species, many if not all are related or identical to common, ubiquitously expressed metabolic enzymes or physiological stress proteins. Of the crystallins present in all vertebrate lenses, the $\alpha$-crystallins are small heat shock proteins (de Jong et al., 1993, Ingolia and Craig, 1982) and the $\beta / \gamma$-crystallins are related to microbial stress proteins (D'Alessio, 2002, Wistow, $1990)$. In addition to its optical role as a crystallin, $\alpha \mathrm{B}$-crystallin remains as a stress-inducible, widely expressed small heat shock protein (Klemenz et al., 1991); both the sibling, lens-specialized $\alpha$ A-crystallins and the small heat shock protein/ $\alpha \mathrm{B}$-crystallin are effective chaperones that protect partially denatured proteins from aggregation in the lens (Horwitz, 1992). This is an important function that retards cataract formation during aging. Most of the taxon-specific crystallins are derived from or are active metabolic enzymes (Piatigorsky, 1992, Tomarev and Piatigorsky, 1996, Wistow and Piatigorsky, 1988). An exception to the rule of taxonspecific crystallins being enzyme-crystallins is 1 -crystallin in the gecko, which is cellular retinol-binding protein type 1 (Werten et al., 2000). Although not an enzyme, $\mathrm{t}$-crystallin has been co-opted from another function for its optical role in the lens. This crystallin hallmark of being recruited from proteins with ubiquitous metabolic functions has led to the idea that crystallins are unified less by their protein phenotype than by their mode of high, lenspreferred gene expression (Carosa et al., 2002, Piatigorsky, 1993, Piatigorsky and Wistow, 1991). We have called the dual use of a single protein encoded in one gene, 'gene sharing' (Piatigorsky et al., 1988, Piatigorsky and Wistow, 1989). An important implication of gene sharing illustrated by the lens crystallins is that a protein can evolve a new role, without losing its original function, by a change in gene expression in the absence of gene duplication (Piatigorsky, 2003a, Piatigorsky and Wistow, 1991). As in other species, cubomedusan jellyfish crystallins are also taxonspecific, borrowed proteins that appear to have non-optical functions. There are three distinct crystallins (J1-, J2- and J3-crystal- lin) in Tripedalialenses (Piatigorsky etal., 1989). Interestingly, the larger, $35 \mathrm{kD} \mathrm{J1-crystallins} \mathrm{are} \mathrm{present} \mathrm{in} \mathrm{the} \mathrm{lenses} \mathrm{of} \mathrm{both} \mathrm{the}$ large and small eyes of the jellyfish rhopalia, while the $20 \mathrm{kD} \mathrm{J2}$ and $19 \mathrm{kD} \mathrm{J3}$-crystallins are confined to the lenses of the larger eyes. None of the Tripedalia crystallins have a sequence relationship to other crystallins in any species. J1-crystallins comprise three distinct polypeptides (J1A, J1B and J1C), each encoded in different, extremely similar genes (Piatigorsky et al., 1993). J1crystallins shows sequence similarity to ADPribosylglycohydrolases (Z. Kozmik and J. Piatigorsky, unpublished data). J2-crystallin does not appear to be related to J1- or J3-crystallins (Piatigorsky et al., 1989), but it has not been cloned yet. More is known about J3-crystallin than about the other crystallins of Tripedalia (Piatigorsky et al., 2001). This protein, encoded in a single-copy gene, is similar in sequence to the conserved saposins, which are multifunctional proteins that bridge lysosomal hydrolases to lipids and activate enzyme activity. Peptides derived from saposins have been also associated with nerve cell survival (Piatigorsky et al., 2001). Interestingly, saposin motifs are present in acid sphingomyelinase and in acyloxyacyl hydrolase in humans, where they participate in regulating enzyme activity. Conceptually, then, the use of saposin sequences as lens crystallins in the jellyfish is akin to having a hybrid molecule displaying characteristics of both chaperones (like the vertebrate $\alpha$-crystallins) and enzymes (like the taxon-specific enzymecrystallins) of vertebrate lenses. As will be described below, this is not unlike the situation where $\mathrm{PaxB}$, a protein with combined functions of Pax2 and Pax6, is employed for eye development in Tripedalia (Kozmik et al., 2003). In addition to the sequence similarities between J3-crystallin and the multifunctional saposins, in situ tests suggest that the $\mathrm{J} 1$ - and $\mathrm{J} 3$-crystallins have nonoptical functions in the jellyfish. Both J1A- and J3-crystallin mRNAs have been detected in the outer lumen of the statocyst (Piatigorsky et al., 2001). Moreover, J3-crystallin RNA is present in curious, alternating bands radiating from the pigmented region of the retina as well as at the tips of the tentacles. Further research is necessary to confirm that these crystallin RNAs are producing their respective crystallin proteins and to discover what noncrystallin function these proteins are serving.

\section{Jellyfish PaxB: an ancestral transcription factor with functional properties of both Pax6 and Pax2/5/8}

Pax proteins are a family of transcriptional regulators characterized by the presence of an evolutionarily conserved DNA binding domain, the paired domain (Bopp et al., 1986, Treisman et al., 1991). The paired domain is a bipartite DNA-binding sequence composed of two helix-turn-helix motifs, the PAI and RED domains (Czerny et al., 1993, Xu et al., 1999, Xu et al., 1995). Based on sequence similarities, Pax proteins can be grouped into four subfamilies, two of which contain a second DNA-binding domain, the paired-type homeodomain (Noll, 1993). Pax genes are involved in many developmental processes in all higher eukaryotes. In particular, Paxgenes have been associated with a number of developmental defects in Drosophila, mouse and human (Chi and Epstein, 2002). The role of the paired- and homeodomain-containing Pax6 during eye development has been characterized extensively (Gehring and Ikeo, 1999). Heterozygote mutations in the human PAXGgene results in aniridia (Glaser 
et al., 1992, Jordan et al., 1992, Ton et al., 1991) and ocular structures are virtually absent in Pax6 homozygote mice (Hill et al., 1991). The observation that mutations in the Drosophila homologue of Pax6result in the eyeless (ey) phenotype (Quiring et al., 1994), along with the facts that misexpression of ey (Halder et al., 1995), toy (the second Pax6gene in Drosophila; Czerny et al., 1999) or Pax6from many other species induces ectopic eyes has led to the proposal of Pax6 being a universal master control gene for eye morphogenesis (Gehring, 2002, Gehring and Ikeo, 1999). Despite the importance of Pax6 in eye development and the presence of eyes in Tripedalia, we have been able to clone only PaxB, not Pax6, from this species (Kozmik et al., 2003). Cnidarian PaxB genes cluster with the Pax2/5/8 subfamily in a phylogenetic tree analysis (Miller et al., 2000). This cluster most likely represents an ancient group of genes within the Pax family since its members were found in sponges (Hoshiyama et al., 1998). Jellyfish PaxBthus corresponds to an ancestral Paxgene encoding a paired domain, homeodomain and an octapeptide between the two domains (Balczarek et al., 1997).

The Pax2/5/8 subfamily consists of a single Drosophilamember, D-Pax2 (Czerny et al., 1997, Fu and Noll, 1997) and three mammalian genes, Pax2, Pax5 and Pax8, which arose by gene duplication at the onset of vertebrate lineage (Pfeffer et al., 1998) and cnidarian PaxB genes(Groger et al., 2000, Kozmik et al., 2003, Sun et al., 2001, Sun et al., 1997). D-Pax2 is required for development of ommatidial cone and pigment cells (sparkling) (Fu and Noll 1997) as well as mechanosensory bristles (shaven) (Fu et al., 1998, Kavaler et al., 1999). In mammals, Pax5 is essential for B-lymphopoiesis (Nutt et al., 1999, Rolink et al., 1999). Loss of Pax2 in mice results in severe kidney, eye and inner ear defects (Torres et al., 1996). In addition, Pax2 collaborates with Pax5in midbrain and cerebellum development (Schwarz et al., 1997, Urbanek et al., 1997). Pax8 deficient mice display thyroid gland dysgenesis (Mansouri et al., 1998). Pax2and Pax8 are required for the specification of the nephric lineage, as mouse embryos lacking both Pax2 and Pax 8 are unable to form the pronephros (Bouchard et al., 2002). Thus, Pax2, which is closely related to PaxB of Tripedalia, plays developmental roles in many tissues as well as in the eye in higher metazoans.

Much less is known about the function of cnidarian PaxB genes. The expression of $P a x B$ has been studied in the hydrozoan Podocoryne carnea (Groger et al., 2000), which does not have eyes. The Podocoryne PaxBgene is expressed in the eggs, the ectodermal layer of larva and endoderm of the developing and adult medusa. Based on the in vitrotransdifferentiation assays, it has been argued that $P a x B$ is involved in nerve cell differentiation (Groger et al., 2000).

The Tripedalia PaxBgene is expressed in swimming larvae as well as in the rhopalia of adult jellyfish (Kozmik etal., 2003). Within the rhopalium PaxBexpression occurs both in the eye (lens and retina) and in the statocyst (Fig. 5A). Interestingly, PaxBexpression shows resemblances to that of vertebrate Pax 6 in the eye and Pax 2/5/8 family members in the eye and inner ear. We have performed a detailed structure-function study of $\mathrm{PaxB}$ protein and have shown that this ancient transcriptional activator represents a functional hybrid of Pax2/5/8 and Pax6 subfamilies (Kozmik et al., 2003). PaxB has a number of Pax $2 / 5 / 8$ features. In addition to having the paired domain DNA-binding specificity of the Pax2/5/ 8 subfamily, PaxB also has a functional transactivation and inhibitory domain characteristic of the Pax $2 / 5 / 8$ class. It has been shown that the $\mathrm{C}$-terminus of all $\mathrm{Pax}$ proteins studied so far carries the transactivation function (Czerny and Busslinger, 1995, Dorfler and Busslinger, 1996, Lechner and Dressler, 1996, Nornes et al., 1996, Tang et al., 1998). Pax6 contains a relatively long transactivation domain composed of shorter regions that act synergistically with each other (Tang et al., 1998). In contrast, Pax2/5/8 proteins have an inhibitory domain in close proximity to a strong, short transactivation domain (Dorfler and Busslinger, 1996, Kreslova et al., 2002). The most prominent Pax6-like feature of $\mathrm{PaxB}$ is a functional homeodomain as a second DNAbinding domain. It was shown previously, that Drosophila Pax6 (ey) directly activates expression of rhodopsingenes through homeodomain binding sites in the proximal region of the promoters(Papatsenko et al., 2001, Sheng et al., 1997). We have shown that PaxBis able to activate the Drosophila rhodopsin rh6

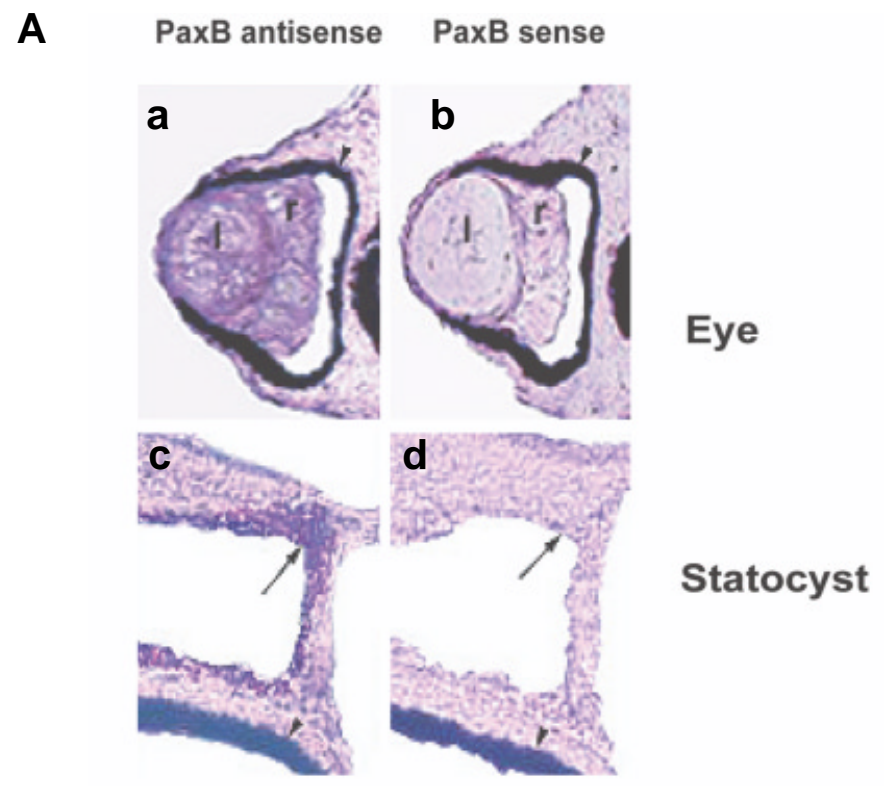

B

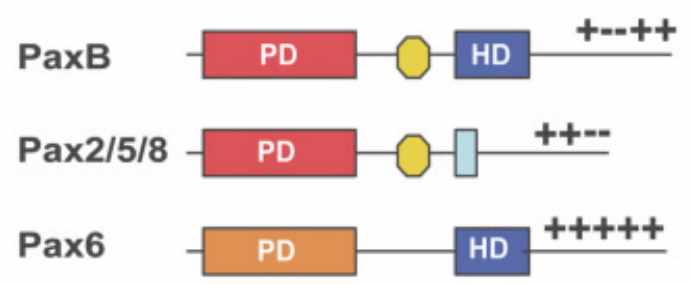

Fig. 5. In situ hybridization and diagrammatic structure of PaxB mRNA. (A) In situ hybridization of PaxB in the lens and retina of the big eye $(a, b)$ and statocyst $(c, d)$ within a Tripedalia rhopalium with PaxB antisense and sense (negative control) probe. Methods are described elsewhere (Kozmik et al., 2003). (B) Schematic drawing of the structure of PaxB, Pax6 and Pax2/5/8 transcription factors. Paired domain ( $P D$, red/brown), octapeptide (yellow) and homeodomain (HD, blue) is indicated. The Cterminus of Pax proteins harbors transactivation (+) and inhibitory (-) domains. 


\section{CNIDARIA}

PAXANCESTOR
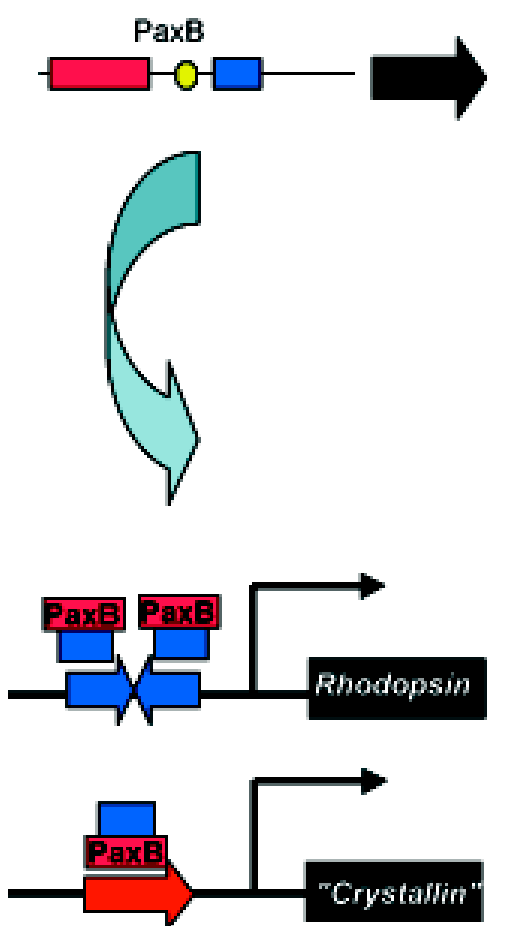

\section{TRIPLOBLASTS}

GENE DUPUCATION

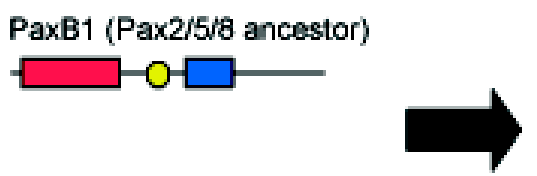

GENE DIVERSIFCATION

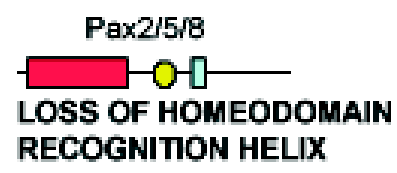

PaxB2 (Pax6 ancestor)

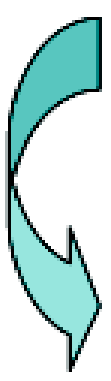

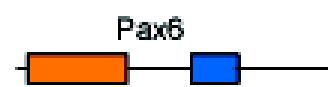

CHANGE IN PAIRED DOMAIN DNA-BINDING SPECIFICITY; LOSS OF OCTAPEPTIDE
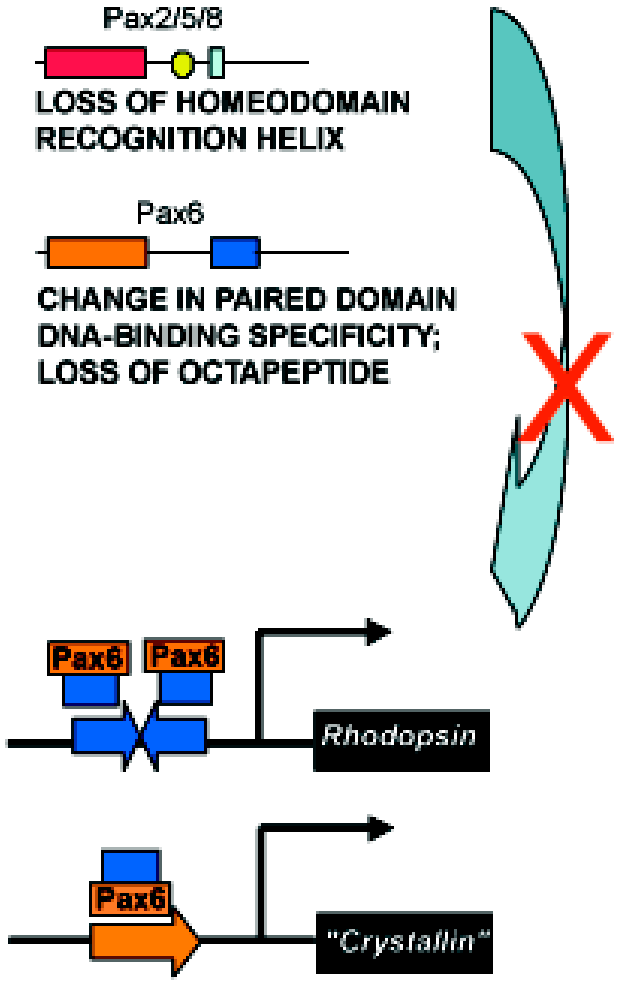

Fig. 6. Hypothesis suggesting that a PaxB-like gene, rather than a modern-like Pax6 gene, was the primordial Pax gene involved in eye formation. The model suggests that a PaxB-like protein was an initial regulator of eye development, of lens crystallin gene expression and of rhodopsin gene expression. In triploblasts, the PaxB gene duplicated, giving rise to early Pax2/5/8 and Pax6 genes. At least in some animal species, Pax 6 has been recruited for the regulation of crystallin and rhodopsin genes.

promoter via its homeodomain in transient transfection assays (Kozmik et al., 2003). Finally, in vivo data using Drosophilaas the test system indicated that $P a x B$ is a multifunctional hybrid protein. It rescues the spa mutation ( $D$-Pax2 deficiency) and, when over expressed, induces ectopic eyes on Drosophila legs (as does Pax6), although with lower efficiency than Pax6 (Kozmik et al., 2003).

\section{A PaxB-like gene was an ancestral regulator of lens crystallin genes}

Pax6 is involved in the regulation of lens crystallin genes in mouse, chicken and guinea pig (Cvekl and Piatigorsky, 1996, Duncan et al., 2004, Duncan et al., 1998, Gopal-Srivastava et al., 1996, Kamachi et al., 2001, Kralova et al., 2002) and, possibly, scallop (Carosa et al., 2002). We have previously identified three major lens crystallins, J1-, J2- and J3-crystallin, in the cellular lenses of Tripedalia (Piatigorsky et al., 1989, Piatigorsky et al., 1993, Piatigorsky et al., 2001). The J3-crystallin gene, expressed primarily in the jellyfish lens and statocyst, appears to be a natural target gene of PaxB (Kozmik et al., 2003). Two paired domain binding sites that fit well with the Pax $2 / 5 / 8$ paired domain consen- sus (Czerny et al., 1993) were identified within the $-66 /-30$ region of the TATA box containing promoter of J3-crystallin gene. PaxB activated expression of the J3-reporter gene construct but not the reporter gene construct in which $\mathrm{PaxB}$ binding sites were mutated. Remarkably, only PaxB (or Pax2) but not vertebrate Pax 6 , Pax1 or Pax3activated the J3-reporter gene in transfection tests (Kozmik et al., 2003). J3-crystallingene activation in jellyfish thus seems to be restricted to $\mathrm{PaxB} / \mathrm{Pax} 2 / 5 / 8$ class of transcription factors.

Mutagenesis tests reinforced the requirement for the Pax2/5/ 8-like paired domain for activation of jellyfish crystallin promoters. Three amino acids (at positions 42, 44 and 47) within the paired domain are responsible for the difference in the DNA-binding specificity between Pax2/5/8 and Pax6. The amino acids IQN at these positions specify the Pax6 class of transcription factors whereas amino acids QRH determine Pax2/5/8 specificity (Czerny and Busslinger, 1995). It is also known that Pax2/5/8 DNA-binding specificity can be generated by converting residues IQN into QRH in positions 42, 44 and 47 of the Pax6 paired domain (Czerny and Busslinger, 1995). In accordance with this data, transfection tests using a $P a \times B(I Q N)$ cDNA encoding a PaxB with a Pax6-like DNAbinding specificity did not activate the $\mathcal{J}$-crystallin promoter 
(Kozmik et al., 2003). We conclude that the Tripedalia J3-crystallinpromoter sequences are optimized for $\mathrm{PaxB} / \mathrm{Pax} 2 / 5 / 8$ and not Pax6 (Kozmik et al., 2003).

\section{Cnidarians suggest that PaxB, not Pax6, was the pri- mordial gene during evolution of complex eyes}

A gene with a typical Pax6-like structure has not been detected in the cubozoan, Tripedalia cystophora (Kozmik et al., 2003) or in the hydrozoans, Podocoryne carnea (Groger et al., 2000) and Cladonema californicum (Sun et al., 2001), despite that Tripedalia and Cladonema have complex eyes. Even if PaxG does exist in Tripedalia but has escaped our efforts to detect its gene or cDNA, our co-transfection tests suggest that the jellyfish Pax6 protein would neither bind nor activate the $\mathcal{J} 3$-crystallinpromoter, as does PaxB (Kozmik et al., 2003). Four Pax genes (PaxA, PaxB, PaxC and $P a x D$ ) have been found in corals (also cnidarians)(Miller et al., 2000). However, none represents a true Pax6ancestor and none has the three characteristic amino acids (IQN) at positions 42, 44 and 47 of the Pax6 paired domain (Kozmik et al., 2003). Analyses of transgenic flies carrying chimeric Paxtransgenes derived from the coral, Acropora millepora, are not consistent with the presence of a classical Pax6gene in cnidarians (Plaza et al., 2003). Thus, although negative results do not establish the absence of Pax 6 , the data suggest that the Pax6gene originated after the separation of Cnidaria from Bilateria. This implies that development of jellyfish eyes were dependent on a PaxB/Pax2/5/8-like and not a Pax6-like protein.

The data indicate that modern Pax2 and Pax6 genes evolved from a $P a x B$ ancestor by duplication and diversification in higher metazoans (Fig. 6). Pax2 lost most of its homeodomain while Pax6 lost the octapeptide and changed the DNA-binding specificity of the paired domain by acquiring amino acids 142, Q44 and N47, respectively. It follows that since Pax2 does not have a functional homeodomain it could no longer regulate expression of rhodopsin genes through homeodomain binding sites, as PaxB appears to be able to do in Tripedalia (Kozmik etal., 2003) (Fig. 6). Consequently, either Pax6 or an unrelated paired-type homeodomain protein took over this function for rhodopsingene expression in triploblastic metazoans. While Pax6homologs eyand/or toyare direct regulators of Drosophila rhodopsingenes $r h 1, r h 3$, rh5and $r h 6$ (Papatsenko et al., 2001, Sheng et al., 1997), the connection between Pax6and rhodopsingene activation is not universal. Remarkably, Pax6has again been recruited for regulation of crystallin genes in vertebrates (Cvekl and Piatigorsky, 1996, Duncan et al., 2004). Since the diverse crystallin genes in different species are structurally unrelated, the recruitment of Pax6for crystallin gene expression in higher metazoa represents convergent evolution.

\section{The Jellyfish eye and other sensory systems and the putative eye/ "ear" connection}

Study of the jellyfish eye has implications for the evolution of other sensory systems. Gehring has reviewed the possibility that the jellyfish eye may have preceded brain evolution (Gehring, 2002). He supports this view by noting that unicellular algae (i.e. Chlamydomonas) or dinoflagellates (i.e. Erythropsis) have eye organelles and no brain. Jellyfish do, however, have a number of specialized ganglia associated with the rhopalia as well as an interconnected nerve ring which may, arguably, be a type of brain for a radially symmetrical animal (Coates, 2003). An attractive feature of eye before brain is that it places sense reception before information processing. Examples of ancestral photoreception preceding a central nervous system are fascinating. One is Chlamydomonas reihhardtii (Roberts et al., 2001). The eyespot of this unicellular alga orchestrates a positive phototaxis in low intensity light and a negative phototaxis in high intensity light by directly affecting the beating pattern of the two attached flagellae. Surprisingly, the Chlamydomonas eye2-1 mutant revealed that formation of the eyespot requires a member of the thioredoxin protein family and that this developmental role does not depend on the catalytic redox capability of the thioredoxin protein. The sponge larva, Reneira sp., provides another example of coordinated phototaxis in a multicellular organism that lacks nerve cells altogether (Leys and Degnan, 2001). A posterior ring of columnar epithelial cells containing a cilia and pigmented-filled protrusions respond directly to light, leading to negative photaxis and directed swimming behavior. Increased light intensity makes the cilia rigid and subsequently bend, shielding the pigmented vesicles; decreased light intensity reverses the process. The resulting negative phototaxis is similar to the shadow response of tunicates and the unicellular Euglena. Spectral sensitivity tests suggest that the photoreceptive pigment in the sponge larva may be a flavin or carotenoid (Leys et al., 2002). This would make the sponge larva the first metazoan not using a rhodopsin-like protein as the primary photoreceptive pigment. It is not known yet whether expression of PaxB, which is present in sponges (Hoshiyama etal., 1998), is associated with the photoreceptive cilia in the sponge larva. Clearly, detailed studies on ancestral eyes and photoresponses are a rich source of new and unexpected insights.

Planula larvae of Tripedalia also have a photoreceptive system that appears to be directly connected to cilia for steering towards particular light conditions. A series of single-cell, pigment cup ocelli, lacking neural connections, surround the posterior half of the larval ectoderm (Nordstrom et al., 2003) (see also Gehring in this issue). The positions of these ocelli vary in different species of cubozoan larvae. These light sensors apparently have photosensitive microvilli and a motor-cilium. The cilium responds directly to light and may act as a rudder to steer the larva. Thus, while ciliated and rhabdomeric photoreceptors are occasionally found in the same species, this is the first instance of the latter being reported in cnidarians.

Early developmental studies on embryonic induction have delineated the complex developmental relationships between the presumptive ear, nose and lens fields (Jacobson, 1963a, Jacobson, 1963b, Jacobson, 1963c). The primary role of Pax6 in eye development (see above) links the visual system with other sensory systems, since Pax6 and other transcription factors that shape the eye are widely expressed in the nervous system (Simpson and Price, 2002, van Heyningen and Williamson, 2002). Interestingly, Pax6 is also expressed in non-neural cells of the visual (i.e. lens, cornea) and olfactory (i.e. sustentacular cells, basal cells and Bowman's glands) systems (Davis and Reed, 1996, Tomarev et al., 1997), linking these distinct sensory modalities.

Our studies on Tridpedalia have revealed an intriguing, putative relationship between evolution of the eye and the inner "ear" (Kozmik et al., 2003, Piatigorsky, 2003b). Like eyes, "ears" (i.e. mechanoreceptors) of invertebrates and vertebrates are believed to be evolu- 


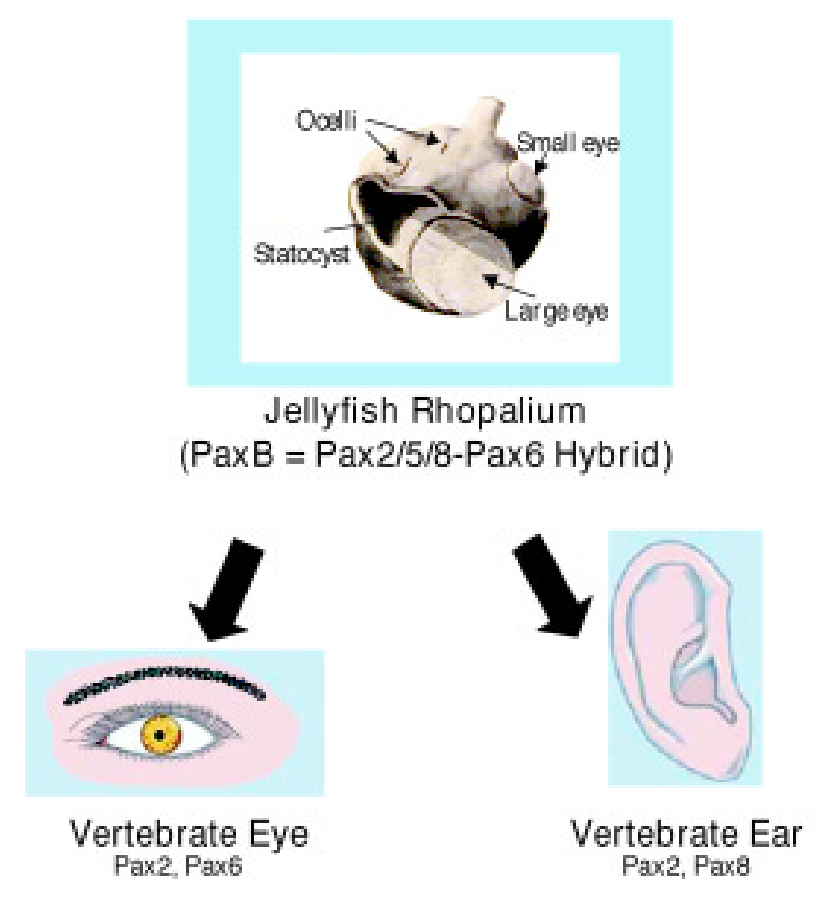

Fig. 7. A scheme suggesting that the eye and the ear may have had a common origin in evolution based on the expression pattern of Pax family members.

tionarily related (Fritzsch and Beisel, 2001, Fritzsch and Beisel, 2003, Jarman, 2002). The rhopalia containing the jellyfish eyes also include a statocyst (see Fig. 3). In general, cnidarian statocysts are associated with mechanoreceptor-like cilia that have been considered as evolutionary ancestors to vertebrate inner ears (Piatigorsky, 2003b, Singla, 1975), with the latter evolving through the stages of sensing water vibrations and then gravity (Horridge, 1969). Despite that mechanoreceptor-like cilia have not been observed directly in the statocysts of Tripedaliaand that statocyst function has not been established in this species (Coates, 2003), it seems likely that the Tripedalia statocysts are related to other cnidarian statocysts that play a role in the "righting response". The relevance of this evolutionary relationship is that $\sqrt{ } 1$ - and $\sqrt{ } 3$-crystallingenes (Piatigorsky et al., 2001) as well as PaxBmRNA (Kozmik et al., 2003), which appears critical for eye development, are expressed in Tripedaliastatocysts, suggesting a connection between eyes and mechanoreceptors (future ears) in the ancient cnidarians. A relationship between PaxB expression and sensory nerve cells has also been noted in the hydrozoan jellyfish, Podocoryne carnea, where PaxBis expressed in the developing tentacle bulbs and edge of the manubrium, sites common to eyes and statocysts of other jellyfish (Groger etal., 2000). Expression of Pax 2/5/8, a PaxBderivative, in mechanosensory cells is conserved throughout evolution, including mammals, lampreys, chordates, ascidians, Haliotis asinine (gastropod mollusk; an abalone), Drosophila, Caenorhabditis elegans (nematode) and other species (O'Brien and Degnan, 2002a, O'Brien and Degnan, 2002b, O'Brien and Degnan, 2003). Perhaps the examples given above of photoreception leading to coordinated behavior by directly controlling ciliary motion in the unicellular alga, as well as the larval sponge and cubozoan jellyfish, represent primordial eye/mechanoreceptors before each sensory system diverged to elaborate either vision (eyes) or mechanoreception (ears).

The hypothesis of an eye/ear evolutionary relationship is reinforced by the fact that PaxB is a hybrid Pax protein, containing a Pax2-like paired domain and octapeptide, but has a Pax6-like homeodomain (Groger et al., 2000, Kozmik et al., 2003, Miller et al., 2000, Sun etal., 2001, Sun etal., 1997) (see Fig. 6). In mammals, ear development depends on Pax2 and eye development depends on both Pax2 and Pax6 (Baker and Bronner-Fraser, 2001, Baker, 2001, Pichaud and Desplan, 2002) (Fig. 7). A number of other transcription factors from the same family (i.e. atonal/Math1, class IV POU, dachschund, six) are used for the development of eyes and ears and discussions can be found elsewhere (Fritzsch and Beisel, 2003, Jarman etal., 1995, Pichaud and Desplan, 2002, van Heyningen and Williamson, 2002). Recent experiments with Drosophila have provided evidence implicating atonal for the formation of segmentspecific sensory organs (Niwa et al., 2004). These authors suggest that various sensory organs, including eyes and mechanoreceptors, evolved from an atona/dependent protosensory organ.

The linkage between eyes and ears has clinical overtones. A functionally important protein overlapping vision and hearing/balance is class III myosin (Dose et al., 2003, Walsh et al., 2002). In Drosophila, the homologous protein, called NINAC, interacts with multiple components to organize the phototransduction machinery into a signaling complex (Wes et al., 1999); NINAC is also responsible for a recessive retinal degeneration in the fly. The human homolog of NINAC, myosin IIIA, is expressed most highly in the retina and ear (cochlea) and recessive loss-of-function mutations of myosin IIIA are associated with hearing loss. A scaffolding protein, harmonin, connected with Usher's syndrome, affecting both vision and hearing, is another clinically intriguing association between these two sensory modalities (Montell, 2000, Verpy et al., 2000). The choroideremia gene also bridges eye and ear diseases (Starr et al., 2004). An example is the human Choroideremiagene, which is responsible for a slow degeneration of rod photoreceptors and retinal pigment cells. Choroideremia encodes Rab escort protein 1 which is essential for prenylation of Rabs. Zebrafish carrying ru848, the recessive homologue of Choroideremia, are unresponsive to acoustic stimuli and lack balance. The recent finding that Norrie disease and familial exudative vitreoretinopathy both implicate a Norrin-Frizzled-4 (a presumptive Wnt receptor) signaling system provide another link between eye and ear pathology in humans (Xu et al., 2004).

Taken together, the jellyfish rhopalia, with their integrated ocelli and statocysts, have provided tantalizing new bits of information relating vision with other sensory modalities that warrant further study. We believe that the sophisticated sensory rhopalia containing anatomically diverse eyes and a statocyst make cubozoan jellyfish, such as Tripedalia, an advantageous model for eye and sensory research.

\section{Acknowledgement \\ Z.K is supported by Center for Integrated Genomics grant LNOOAO79.}

\section{References}

ARENDT, D. and WITTBRODT, J. (2001). Reconstructing the eyes of Urbilateria. Philos Trans R Soc Lond B Biol Sci356: 1545-63.

BAKER, C.V. and BRONNER-FRASER, M. (2001). Vertebrate cranial placodes i. Embryonic induction. Dev Bio/232: 1-61. 
BAKER, N.E. (2001). Master regulatory genes; telling them what to do. Bioessays 23: 763-6.

BALCZAREK, K.A., LAI, Z.C. and KUMAR, S. (1997). Evolution of functional diversification of the paired box (Pax) DNA-binding domains. Mol Biol Evol14: 829-42.

BALL, E.E., HAYWARD, D.C., REECE-HOYES, J.S., HISLOP, N.R., SAMUEL, G., SAINT, R., HARRISON, P.L. and MILLER, D.J. (2002). Coral development: From classical embryology to molecular control. Int J Dev Bio/46: 671-8.

BOPP, D., BURRI, M., BAUMGARTNER, S., FRIGERIO, G. and NOLL, M. (1986). Conservation of a large protein domain in the segmentation gene paired and in functionally related genes of Drosophila. Cel/47: 1033-40.

BOUCHARD, M., SOUABNI, A., MANDLER, M., NEUBUSER, A. and BUSSLINGER, M. (2002). Nephric lineage specification by Pax2 and Pax8. Genes Dev16: 295870.

CALLAERTS, P., MUNOZ-MARMOL, A.M., GLARDON, S., CASTILLO, E., SUN, H. LI, W.H., GEHRING, W.J. and SALO, E. (1999). Isolation and expression of a Pax6 gene in the regenerating and intact planarian Dugesia(G)Tigrina. ProcNat/Acad Sci USA 96: 558-63.

CAROSA, E., KOZMIK, Z., RALL, J.E. and PIATIGORSKY, J. (2002). Structure and expression of the scallop omega-crystallin gene. Evidence for convergent evolution of promoter sequences. J Biol Chem 277: 656-64.

CHI, N. and EPSTEIN, J.A. (2002). Getting your Pax straight: Pax proteins in development and disease. Trends Genet 18: 41-7.

COATES, M.M. (2003). Visual ecology and functional morphology of cubuzoa (cnidaria). Integr. Comp. Biol. 43: 542-548

CONANT, F.S. (1897). Notes on the cubomedusae. Johns Hopkins Univ CircNo. 132: 8-10.

CONWAYMORRIS, S. (2000). The cambrian «explosion»: Slow-fuse or megatonnage? Proc Natl Acad Sci USA 97: 4426-9.

CVEKL, A. and PIATIGORSKY, J. (1996). Lens development and crystallin gene expression: Many roles for Pax-6. Bioessays 18: 621-30.

CZERNY, T., BOUCHARD, M., KOZMIK, Z. and BUSSLINGER, M. (1997). The characterization of novel Pax genes of the sea urchin and Drosophila reveal an ancient evolutionary origin of the Pax2/5/8 subfamily. Mech Dev67: 179-92.

CZERNY, T. and BUSSLINGER, M. (1995). DNA-binding and transactivation properties of Pax-6: Three amino acids in the paired domain are responsible for the different sequence recognition of Pax-6 and BSAP (Pax-5). Mo/Ce// Bio/15: 285871.

CZERNY, T., HALDER, G., KLOTER, U., SOUABNI, A., GEHRING, W.J. and BUSSLINGER, M. (1999). Twin of eyeless, a second Pax-6 gene of Drosophila, acts upstream of eyeless in the control of eye development. Mo/ Cel/3: 297-307.

CZERNY, T., SCHAFFNER, G. and BUSSLINGER, M. (1993). DNA sequence recognition by $P$ ax proteins: Bipartite structure of the paired domain and its binding site. Genes Dev 7: 2048-61.

D'ALESSIO, G. (2002). The evolution of monomeric and oligomeric betagamma-type crystallins. Facts and hypotheses. Eur J Biochem 269: 3122-30.

DAVIS, J.A. and REED, R.R. (1996). Role of Olf-1 and Pax-6 transcription factors in neurodevelopment. JNeurosci 16: 5082-94.

DE JONG, W.W., HENDRIKS, W., MULDERS, J.W. and BLOEMENDAL, H. (1989). Evolution of eye lens crystallins: The stress connection. Trends Biochem Sci14: 365-8.

DE JONG, W.W., LEUNISSEN, J.A. and VOORTER, C.E. (1993). Evolution of the alpha-crystallin/small heat-shock protein family. Mol Biol Evol10: 103-26.

DORFLER, P. and BUSSLINGER, M. (1996). C-terminal activating and inhibitory domains determine the transactivation potential of BSAP (Pax-5), Pax-2 and Pax8. EMBO J15: 1971-82.

DOSE, A.C., HILLMAN, D.W., WONG, C., SOHLBERG, L., LIN-JONES, J. and BURNSIDE, B. (2003). Myo3A, one of two class III myosin genes expressed in vertebrate retina, is localized to the calycal processes of rod and cone photoreceptors and is expressed in the sacculus. Mol Biol Cel/14: 1058-73.

DUNCAN, M.K., CVEKL, A., KANTOROW, M. and PIATIGORSKY, J. (2004). Lens crystallins. In Development of the ocular lens, (ed. ROBINSON, M. L. and LOVICU, F. J.). Cambridge University Press, New York.

DUNCAN, M.K., HAYNES, J.I., 2ND, CVEKL, A. and PIATIGORSKY, J. (1998). Dual roles for Pax-6: A transcriptional repressor of lens fiber cell-specific beta-crystallin genes. Mol Cell Biol18: 5579-86.
EAKIN, R. (1979). Evolutionary significance of photoreceptors: In retrospect. American Zoologist 19: 647-653.

EAKIN, R.A.W., JA. (1962). Fine structrue of photoreceptors in the hydromedusan, Polyorchis penicillatus. Proc. Natl Acad. Sci. USA 48: 826-833.

FRITZSCH, B. and BEISEL, K.W. (2001). Evolution and development of the vertebrate ear.Brain Res Bull55: 711-21.

FRITZSCH, B. and BEISEL, K.W. (2003). Keeping sensory cells and evolving neurons to connect them to the brain: Molecular conservation and novelties in vertebrate ear development. In Development of the auditory and vestibular systems. Current topics in developmentalbiology, vol. 57 (ed. ROMAND, R. and VARELA-NIETO, I.), pp.1-48.

FU, W., DUAN, H., FREI, E. and NOLL, M. (1998). Shaven and sparkling are mutations in separate enhancers of the Drosophila Pax2 homolog. Development 125: 2943-50.

FU, W. and NOLL, M. (1997). The Pax2 homolog sparkling is required for development of cone and pigment cells in the Drosophila eye. Genes Dev11: 2066-78.

GALLIOT, B. and SCHMID, V. (2002). Cnidarians as a model system for understanding evolution and regeneration. Int J Dev Bio/46: 39-48.

GEHRING, W.J. (2002). The genetic control of eye development and its implications for the evolution of the various eye-types. Int J Dev Bio/46: 65-73.

GEHRING, W.J. and IKEO, K. (1999). Pax 6: Mastering eye morphogenesis and eye evolution. Trends Genet 15: 371-7.

GLARDON, S., CALLAERTS, P., HALDER, G. and GEHRING, W.J. (1997). Conservation of Pax- 6 in a lower chordate, the ascidian Phallusia mammillata. Development 124: 817-25.

GLARDON, S., HOLLAND, L.Z., GEHRING, W.J. and HOLLAND, N.D. (1998). Isolation and developmental expression of the amphioxus Pax-6 gene (AmphiPax6): Insights into eye and photoreceptor evolution. Development 125: 2701-10.

GLASER, T., WALTON, D.S. and MAAS, R.L. (1992). Genomic structure, evolutionary conservation and aniridia mutations in the human Pax6 gene. Nat Genet 2: $232-9$.

GOPAL-SRIVASTAVA, R., CVEKL, A. and PIATIGORSKY, J. (1996). Pax-6 and alphaB-crystallin/small heat shock protein gene regulation in the murine lens. Interaction with the lens-specific regions, LSR1 and LSR2. J Biol Chem 271: 23029-36.

GROGER, H., CALLAERTS, P., GEHRING, W.J. and SCHMID, V. (2000). Characterization and expression analysis of an ancestor-type Pax gene in the hydrozoan jellyfish Podocoryne carnea. Mech Dev 94: 157-69.

GROGER, H. and SCHMID, V. (2001). Larval development in cnidaria: A connection to bilateria? Genesis 29: 110-4

HALDER, G., CALLAERTS, P. and GEHRING, W.J. (1995). Induction of ectopic eyes by targeted expression of the eyeless gene in Drosophila. Science 267: 1788-92.

HANSON, I.M. (2001). Mammalian homologues of the Drosophila eye specification genes. Semin Cell Dev Biol12: 475-84.

HAYWARD, D.C., SAMUEL, G., PONTYNEN, P.C., CATMULL, J., SAINT, R., MILLER, D.J. and BALL, E.E. (2002). Localized expression of a dpp/BMP2/4 ortholog in a coral embryo. Proc Nat/ Acad Sci USA 99: 8106-11.

HEANUE, T.A., RESHEF, R., DAVIS, R.J., MARDON, G., OLIVER, G., TOMAREV, S., LASSAR, A.B. and TABIN, C.J. (1999). Synergistic regulation of vertebrate muscle development by Dach2, Eya2, and Six1, homologs of genes required for Drosophila eye formation. Genes Dev 13: 3231-43.

HILL, R.E., FAVOR, J., HOGAN, B.L., TON, C.C., SAUNDERS, G.F., HANSON, I.M., PROSSER, J., JORDAN, T., HASTIE, N.D. and VAN HEYNINGEN, V. (1991). Mouse small eye results from mutations in a paired-like homeoboxcontaining gene. Nature 354: 522-5.

HORRIDGE, G.A. (1969). Statocysts of medusae and evolution of stereocilia. Tissue \& Cel/ $1: 341-353$

HORWITZ, J. (1992). Alpha-crystallin can function as a molecular chaperone. Proc Nat/ Acad Sci USA 89: 10449-53.

HOSHIYAMA, D., SUGA, H., IWABE, N., KOYANAGI, M., NIKOH, N., KUMA, K., MATSUDA, F., HONJO, T. and MIYATA, T. (1998). Sponge Pax cDNA related to $\mathrm{Pax}-2 / 5 / 8$ and ancient gene duplications in the Pax family. $J \mathrm{Mo} /$ Evo/47: 640-8. 
HYMAN, L. (1940). The invertebrates: Protozoa through ctenophora. McGraw-Hill Book Co., Inc. New York.

INGOLIA, T.D. and CRAIG, E.A. (1982). Four small Drosophila heat shock proteins are related to each other and to mammalian alpha-crystallin. Proc Natl $\mathrm{Acad} S \mathrm{Cl}$ USA 79: 2360-4.

JACOBSON, A.G. (1963a). The determination and positioning of the nose, lens and ear. I. Interactions within the ectoderm, and between the ectoderm and underlying tissues. J Exp Zoo/154: 273-83.

JACOBSON, A.G. (1963b). The determination and positioning of the nose, lens and ear. li. The role of the endoderm. J Exp Zoo/154: 285-91.

JACOBSON, A.G. (1963c). The determination and positioning of the nose, lens and ear. lii. Effects of reversing the antero-posterior axis of epidermis, neural plate and neural fold. J Exp Zoo/154: 293-303.

JARMAN, A.P. (2002). Studies of mechanosensation using the fly. Hum Mo/Genet11: 1215-8.

JARMAN, A.P., SUN, Y., JAN, L.Y. and JAN, Y.N. (1995). Role of the proneural gene, atonal, in formation of Drosophila chordotonal organs and photoreceptors. Deve/opment 121: 2019-30

JORDAN, T., HANSON, I., ZALETAYEV, D., HODGSON, S., PROSSER, J., SEAWRIGHT, A., HASTIE, N. and VAN HEYNINGEN, V. (1992). The human PAX6 gene is mutated in two patients with aniridia. Nat Genet 1: 328-32.

KADOR, P.F., ZIGLER, J.S. and KINOSHITA, J.H. (1979). Alterations of lens protein synthesis in galactosemic rats. Invest Ophthalmol Vis Sci18: 696-702.

KAMACHI, Y., UCHIKAWA, M., TANOUCHI, A., SEKIDO, R. and KONDOH, H. (2001). Pax6 and Sox2 form a co-DNA-binding partner complex that regulates initiation of lens development. Genes Dev15: 1272-86.

KAVALER, J., FU, W., DUAN, H., NOLL, M. and POSAKONY, J.W. (1999). An essential role for the Drosophila Pax2 homolog in the differentiation of adult sensory organs. Development 126: 2261-72.

KLEMENZ, R., FROHLI, E., STEIGER, R.H., SCHAFER, R. and AOYAMA, A. (1991). Alpha B-crystallin is a small heat shock protein. Proc Nat/ Acad Sci USA 88: 36526.

KOSTROUCH, Z., KOSTROUCHOVA, M., LOVE, W., JANNINI, E., PIATIGORSKY, J. and RALL, J.E. (1998). Retinoic acid $x$ receptor in the diploblast, Tripedalia cystophora. Proc Natl Acad Sci USA 95: 13442-7.

KOZMIK, Z., DAUBE, M., FREI, E., NORMAN, B., KOS, L., DISHAW, L.J., NOLL, M. and PIATIGORSKY, J. (2003). Role of Pax genes in eye evolution. A cnidarian PaxB gene uniting Pax2 and Pax6 functions. Dev Cel/5: 773-85.

KRALOVA, J., CZERNY, T., SPANIELOVA, H., RATAJOVA, V. and KOZMIK, Z. (2002). Complex regulatory element within the gammaE- and gammaF-crystallin enhancers mediates Pax6 regulation and is required for induction by retinoic acid. Gene 286: 271-82.

KRESLOVA, J., HOLLAND, L.Z., SCHUBERT, M., BURGTORF, C., BENES, V. and KOZMIK, Z. (2002). Functional equivalency of amphioxus and vertebrate Pax258 transcription factors suggests that the activation of mid-hindbrain specific genes in vertebrates occurs via the recruitment of Pax regulatory elements. Gene282: 14350 .

KUMAR, J.P. and MOSES, K. (2001a). EGF receptor and Notch signaling act upstream of eyeless/Pax6 to control eye specification. Cel/104: 687-97.

KUMAR, J.P. and MOSES, K. (2001b). Eye specification in Drosophila. Perspectives and implications. Semin Cell Dev Biol12: 469-74.

LAND, M.F. and NILSSON, D.-E. (2002). Animaleyes. Oxford University Press, Oxford.

LASKA, V.G. and HUNDGEN, M. (1982). Morphologie und ultrastruktur der lichtsinnesorgane von Tridpedalia cystophora Conant (Cnidaria, Cubozoa). Zool. Jb. Anat. 108: 107-123.

LECHNER, M.S. and DRESSLER, G.R. (1996). Mapping of Pax-2 transcription activation domains. J Biol Chem 271: 21088-93.

LEYS, S.P., CRONIN, T.W., DEGNAN, B.M. and MARSHALL, J.N. (2002). Spectral sensitivity in a sponge larva. J Comp Physiol A Neuroethol Sens Neural Behav Physiol188: 199-202.

LEYS, S.P. and DEGNAN, B.M. (2001). Cytological basis of photoresponsive behavior in a sponge larva. Biol Bul/201: 323-38.

LOOSLI, F., KMITA-CUNISSE, M. and GEHRING, W.J. (1996). Isolation of a Pax-6 homolog from the ribbonworm Lineus sanguineus. Proc Natl Acad Sci USA 93: 2658-63.
MANSOURI, A., CHOWDHURY, K. and GRUSS, P. (1998). Follicular cells of the thyroid gland require Pax8 gene function. Nat Genet 19: 87-90.

MILLER, D.J., HAYWARD, D.C., REECE-HOYES, J.S., SCHOLTEN, I., CATMULL, J., GEHRING, W.J., CALLAERTS, P., LARSEN, J.E. and BALL, E.E. (2000). Pax gene diversity in the basal cnidarian Acropora millepora (cnidaria, anthozoa): Implications for the evolution of the Pax gene family. Proc Nat/ Acad Sci USA 97: 4475-80.

MONTELL, C. (2000). A PDZ protein ushers in new links. Nat Genet 26: 6-7.

NILSSON, D.E. and PELGER, S. (1994). A pessimistic estimate of the time required for an eye to evolve. Proc $R$ Soc Lond B Biol Sci256: 53-8.

NIWA, N., HIROMI, Y. and OKABE, M. (2004). A conserved developmental program for sensory organ formation in Drosophila melanogaster. Nat Genet 36: 293-7.

NOLL, M. (1993). Evolution and role of Pax genes. Curr Opin Genet Dev3: 595-605.

NORDSTROM, K., WALLEN, R., SEYMOUR, J. and NILSSON, D. (2003). A simple visual system without neurons in jellyfish larvae. Proc $R$ Soc Lond B Biol Sci270: 2349-54

NORNES, S., MIKKOLA, I., KRAUSS, S., DELGHANDI, M., PERANDER, M. and JOHANSEN, T. (1996). Zebrafish Pax9 encodes two proteins with distinct Cterminal transactivating domains of different potency negatively regulated by adjacent N-terminal sequences. J Biol Chem 271: 26914-23.

NUTT, S.L., HEAVEY, B., ROLINK, A.G. and BUSSLINGER, M. (1999). Commitment to the B-lymphoid lineage depends on the transcription factor Pax5. Nature 401 556-62.

O'BRIEN, E.K. and DEGNAN, B.M. (2002a). Developmental expression of a class IV $P O U$ gene in the gastropod Haliotis asinina supports a conserved role in sensory cell development in bilaterians. Dev Genes Evo/212: 394-8.

O'BRIEN, E.K. and DEGNAN, B.M. (2002b). Pleiotropic developmental expression of HasPOU-III, a class IIIpou gene, in the gastropod Haliotis asinina. Mech Dev114: 129-32.

O'BRIEN, E.K. and DEGNAN, B.M. (2003). Expresson of Pax258 in the gastropod statocyst: Insights into the antiquity of metazoan geosensory organs. Evol Dev5: 572-578.

PACKARD, A. (1972). Cephalopods and fish: The limits of convergence. Biol. Rev. 47: 241-307.

PAPATSENKO, D., NAZINA, A. and DESPLAN, C. (2001). A conserved regulatory element present in all Drosophila rhodopsin genes mediates Pax6 functions and participates in the fine-tuning of cell-specific expression. Mech Dev101: 143-53.

PEARSE, J.S. and PEARSE, V.B. (1978). Vision of cubomedusan jellyfishes. Science 199: 458.

PFEFFER, P.L., GERSTER, T., LUN, K., BRAND, M. and BUSSLINGER, M. (1998). Characterization of three novel members of the zebrafish $P a x 2 / 5 / 8$ family: Dependency of Pax5 and Pax8 expression on the Pax2.1 (noi) function. Development 125: 3063-74.

PIATIGORSKY, J. (1984). Delta crystallins and their nucleic acids. Mol Cell Biochem 59: 33-56.

PIATIGORSKY, J. (1992). Lens crystallins. Innovation associated with changes in gene regulation. J Biol Chem 267: 4277-80.

PIATIGORSKY, J. (1993). Puzzle of crystallin diversity in eye lenses. Dev Dyn 196: 267-72.

PIATIGORSKY, J. (2003a). Crystallin genes: Specialization by changes in gene regulation may precede gene duplication. J Struct Funct Genomics 3: 131-7.

PIATIGORSKY, J. (2003b). Gene sharing, lens crystallins and speculations on an eye/ear evolutionary relationship. Integr. Comp. Biol. 43: 492-499.

PIATIGORSKY, J., HORWITZ, J., KUWABARA, T. and CUTRESS, C.E. (1989). The cellular eye lens and crystallins of cubomedusan jellyfish. J Comp Physiol [A]164: 577-87.

PIATIGORSKY, J., HORWITZ, J. and NORMAN, B.L. (1993). J1-crystallins of the cubomedusan jellyfish lens constitute a novel family encoded in at least three intronless genes. J Biol Chem 268: 11894-901.

PIATIGORSKY, J., NORMAN, B., DISHAW, L.J., KOS, L., HORWITZ, J., STEINBACH P.J. and KOZMIK, Z. (2001). J3-crystallin of the jellyfish lens: Similarity to saposins. Proc Natl Acad Sci USA 98: 12362-7.

PIATIGORSKY, J., O'BRIEN, W.E., NORMAN, B.L., KALUMUCK, K., WISTOW, G.J., BORRAS, T., NICKERSON, J.M. and WAWROUSEK, E.F. (1988). Gene sharing 
by delta-crystallin and argininosuccinate lyase. Proc Nat/ Acad Sci USA 85: 347983.

PIATIGORSKY, J. and WISTOW, G. (1991). The recruitment of crystallins: New functions precede gene duplication. Science 252: 1078-9.

PIATIGORSKY, J. and WISTOW, G.J. (1989). Enzyme/crystallins: Gene sharing as an evolutionary strategy. Cel/57: 197-9.

PICHAUD, F. and DESPLAN, C. (2002). Pax genes and eye organogenesis. Curr Opin Genet Dev 12: 430-4.

PICHAUD, F., TREISMAN, J. and DESPLAN, C. (2001). Reinventing a common strategy for patterning the eye. Cel/105: 9-12.

PLAZA, S., DE JONG, D.M., GEHRING, W.J. and MILLER, D.J. (2003). DNA-binding characteristics of cnidarian $\mathrm{Pax}-\mathrm{C}$ and $\mathrm{Pax}-\mathrm{B}$ proteins in vivo and in vitro. No simple relationship with the Pax-6 and Pax-2/5/8 classes. J Exp Zoolog Part BMol Dev Evo/299: 26-35.

QUIRING, R., WALLDORF, U., KLOTER, U. and GEHRING, W.J. (1994). Homology of the eyeless gene of Drosophila to the small eye gene in mice and Aniridia in humans. Science 265: 785-9.

RELAIX, F. and BUCKINGHAM, M. (1999). From insect eye to vertebrate muscle: Redeployment of a regulatory network. Genes Dev 13: 3171-8.

ROBERTS, D.G., LAMB, M.R. and DIECKMANN, C.L. (2001). Characterization of the EYE2 gene required for eyespot assembly in Chlamydomonas reinhardtii. GenetiCs 158: $1037-49$

ROLINK, A.G., NUTT, S.L., MELCHERS, F. and BUSSLINGER, M. (1999). Long-term in vivo reconstitution of t-cell development by Pax5-deficient B-cell progenitors. Nature 401: 603-6.

SCHWARZ, M., ALVAREZ-BOLADO, G., URBANEK, P., BUSSLINGER, M. and GRUSS, P. (1997). Conserved biological function between Pax-2 and Pax-5 in midbrain and cerebellum development: Evidence from targeted mutations. Proc Nat/ Acad Sci USA 94: 14518-23.

SHENG, G., THOUVENOT, E., SCHMUCKER, D., WILSON, D.S. and DESPLAN, C. (1997). Direct regulation of rhodopsin 1 by Pax-6/eyeless in Drosophila: Evidence for a conserved function in photoreceptors. Genes Dev 11: 1122-31.

SIMPSON, T.I. and PRICE, D.J. (2002). Pax6; a pleiotropic player in development. Bioessays 24: 1041-51.

SINGLA, C.L. (1974). Ocelli of hydromedusae. Cell Tissue Res 149: 413-29.

SINGLA, C.L. (1975). Staocysts of hydromedusae. Cell Tissue Res 158: 391-407.

STARR, C.J., KAPPLER, J.A., CHAN, D.K., KOLLMAR, R. and HUDSPETH, A.J. (2004). Mutation of the zebrafish choroideremia gene encoding Rab escort protein 1 devastates hair cells. Proc Nat/ Acad Sci USA 101: 2572-7.

SUN, H., DICKINSON, D.P., COSTELLO, J. and LI, W.H. (2001). Isolation of Cladonema Pax-B genes and studies of the DNA-binding properties of cnidarian Pax paired domains. Mol Biol Evol18: 1905-18.

SUN, H., RODIN, A., ZHOU, Y., DICKINSON, D.P., HARPER, D.E., HEWETTEMMETT, D. and LI, W.H. (1997). Evolution of paired domains: Isolation and sequencing of jellyfish and hydra Pax genes related to Pax-5 and Pax-6. ProcNat/ Acad Sci USA 94: 5156-61.

TANG, H.K., SINGH, S. and SAUNDERS, G.F.(1998). Dissection of the transactivation function of the transcription factor encoded by the eye developmental gene Pax 6 . J Biol Chem 273: 7210-21.

TOMAREV, S.I., CALLAERTS, P., KOS, L., ZINOVIEVA, R., HALDER, G., GEHRING, W. and PIATIGORSKY, J. (1997). Squid Pax-6 and eye development. Proc Nat/ Acad Sci USA 94: 2421-6.

TOMAREV, S.I. and PIATIGORSKY, J. (1996). Lens crystallins of invertebratesdiversity and recruitment from detoxification enzymes and novel proteins. Eur $J$ Biochem 235: 449-65

TON, C.C., HIRVONEN, H., MIWA, H., WEIL, M.M., MONAGHAN, P., JORDAN, T., VAN HEYNINGEN, V., HASTIE, N.D., MEIJERS-HEIJBOER, H., DRECHSLER, M. et al. (1991). Positional cloning and characterization of a paired box- and homeobox-containing gene from the aniridia region. Cel/67: 1059-74.
TORRES, M., GOMEZ-PARDO, E. and GRUSS, P. (1996). Pax2 contributes to inner ear patterning and optic nerve trajectory. Development 122: 3381-91.

TREISMAN, J., HARRIS, E. and DESPLAN, C. (1991). The paired box encodes a second DNA-binding domain in the paired homeo domain protein. Genes Dev5: 594-604.

URBANEK, P., FETKA, I., MEISLER, M.H. and BUSSLINGER, M. (1997). Cooperation of Pax2 and Pax5 in midbrain and cerebellum development. Proc Nat/ Acad Sci USA 94: 5703-8.

VAN HEYNINGEN, V. and WILLIAMSON, K.A. (2002). Pax6 in sensory development. Hum Mol Genet 11: 1161-7.

VERPY, E., LEIBOVICI, M., ZWAENEPOEL, I., LIU, X.Z., GAL, A., SALEM, N., MANSOUR, A., BLANCHARD, S., KOBAYASHI, I., KEATS, B.J. et al. (2000). A defect in harmonin, a PDZ domain-containing protein expressed in the inner ear sensory hair cells, underlies Usher syndrome type 1C. Nat Genet26: 51-5.

WALSH, T., WALSH, V., VREUGDE, S., HERTZANO, R., SHAHIN, H., HAIKA, S., LEE, M.K., KANAAN, M., KING, M.C. and AVRAHAM, K.B. (2002). From flies' eyes to our ears: Mutations in a human class III myosin cause progressive nonsyndromic hearing loss DFNB30. Proc Natl Acad Sci USA 99: 7518-23.

WEBER, C. (1981). Structure, histochemistry, ontogenetic development and regeneration of the ocellus of Cladonema radiatum dujardin (Cnidaria, Hydrozoa, Anthomedusae). J. Morphol. 161: 313-331.

WERNER, B., CHAPMAN, D.M, AND CUTRESS, C.E. (1976). Muscular and nervous systems of the cubopolyp (Cnidaria). Experientia 32: 1047-1048.

WERNER, B., CUTRESS, C.E. AND STUDEBAKER, J.P. (1971). Life cycle of Tripedalia cystophora Conant (Cubomedusae). Nature 232: 582-583.

WERTEN, P.J., ROLL, B., VAN AALTEN, D.M. and DE JONG, W.W. (2000). Gecko iota-crystallin: How cellular retinol-binding protein became an eye lens ultraviolet filter. Proc Natl Acad Sci USA 97: 3282-7.

WES, P.D., XU, X.Z., LI, H.S., CHIEN, F., DOBERSTEIN, S.K. and MONTELL, C. (1999). Termination of phototransduction requires binding of the NINAC myosin III and the PDZ protein INAD. Nat Neurosci2: 447-53.

WEST, J.A., SIVAK, J.G. and DOUGHTY, M.J. (1995). Microscopical evaluation of the crystalline lens of the squid (Loligo opalescens) during embryonic development. Exp Eye Res 60: 19-35.

WEST, J.A., SIVAK, J.G., PASTERNAK, J. and PIATIGORSKY, J. (1994) Immunolocalization of S-crystallins in the developing squid (Loligo opalescens) lens. Dev Dyn 199: 85-92.

WISTOW, G. (1990). Evolution of a protein superfamily: Relationships between vertebrate lens crystallins and microorganism dormancy proteins. $\mathrm{JMO} / \mathrm{EvO} / 30$ : 140-5.

WISTOW, G.J. and PIATIGORSKY, J. (1988). Lens crystallins: The evolution and expression of proteins for a highly specialized tissue. Annu Rev Biochem 57: 479 504.

XU, H.E., ROULD, M.A., XU, W., EPSTEIN, J.A., MAAS, R.L. and PABO, C.O. (1999). Crystal structure of the human Pax6 paired domain-DNA complex reveals specific roles for the linker region and carboxy-terminal subdomain in DNA binding. Genes Dev 13: 1263-75.

XU, Q., WANG, Y., DABDOUB, A., SMALLWOOD, P.M., WILLIAMS, J., WOODS, C., KELLEY, M.W., JIANG, L., TASMAN, W., ZHANG, K. et al. (2004). Vascular development in the retina and inner ear: Control by Norrin and Frizzled-4, a highaffinity ligand-receptor pair. Cel/116: 883-95

XU, W., ROULD, M.A., JUN, S., DESPLAN, C. and PABO, C.O. (1995). Crystal structure of a paired domain-DNA complex at 2.5 a resolution reveals structural basis for Pax developmental mutations. Cel/80: 639-50.

YAMASU, T. and YOSHIDA, M. (1976). Fine structure of complex ocelli of a cubomedusan, Tamoya bursaria Haeckel. Cell Tissue Res 170: 325-39.

ZUBER, M.E., GESTRI, G., VICZIAN, A.S., BARSACCHI, G. and HARRIS, W.A. (2003). Specification of the vertebrate eye by a network of eye field transcription factors. Development 130: 5155-67. 